\title{
Temperature and daylength regulate encystment in calcareous cyst-forming dinoflagellates
}

\author{
S. Sgrosso, F. Esposito, M. Montresor* \\ Stazione Zoologica ‘A. Dohrn', Villa Comunale, 80121 Napoli, Italy
}

\begin{abstract}
We tested the effect of temperature $\left(15,20\right.$, and $\left.25^{\circ} \mathrm{C}\right)$, daylength $(8: 16,12: 12$ and $16: 8 \mathrm{~h}$ light:dark cycles), and culture medium (K/5 and K/50) conditions on cyst production in batch cultures of 4 dinoflagellate species that form calcareous resting stages (Scrippsiella trochoidea var. aciculifera, Pentapharsodinium tyrrhenicum, Calciodinellum operosum and $S$. rotunda). The 4 species showed different encystment patterns at the temperature conditions tested; cyst production was inversely related to daylength conditions, and higher cyst yields were obtained with the less concentrated growth medium. Experiments with semi-continuous cultures of $S$. rotunda, in which nutrient concentration was kept within values comparable to in situ concentrations, were carried out with the aim of decoupling the effect of nutrient depletion on cyst production from that of daylength. Cyst production in this species, kept at a constant growth rate in non-depleted nutrient conditions, was only obtained at the shortest daylengths, thus supporting the role of short daylength in inducing the production of calcareous cysts. Our data suggest that encystment in the 4 species is regulated by a complex interplay of at least 3 factors: daylength, temperature and nutrient concentration. These results contribute to explain the timing of resting-stage production at sea, and point to the possible role of daylength as an environmental signal for the regulation of life cycles in dinoflagellates.
\end{abstract}

KEY WORDS: Calcareous cysts $\cdot$ Cysts $\cdot$ Daylength $\cdot$ Dinoflagellates $\cdot$ Encystment $\cdot$ Calciodinellum Scrippsiella $\cdot$ Pentapharsodinium

Resale or republication not permitted without written consent of the publisher

\section{INTRODUCTION}

Calcareous cysts produced by autotrophic orthoperidinioids (Wall \& Dale 1968, Lewis 1991, Montresor et al. 1994, D'Onofrio et al. 1999) and the coccoid cell of Thoracosphaera heimii (Tangen et al. 1982) are the only dinoflagellate stages endowed with a layer of biogenic calcium carbonate. Calcareous cysts are abundant in neritic environments (e.g. Ellegaard et al. 1994, Nehring 1995, Ishikawa \& Taniguchi 1996, Montresor et al. 1998) and they constitute the dominant cyst morphotype produced in tropical oceanic waters (Dale 1992). These resting stages also have an extensive fossil record (Keupp 1991) and they are candidate paleoecologic indicators (Höll et al. 1999, Zonneveld et al. 1999).

\footnotetext{
*Corresponding author. E-mail: mmontr@alpha.szn.it
}

Calcareous cysts constitute a significant fraction of the total cyst assemblage in the Gulf of Naples (Mediterranean Sea), where different seasonal patterns of cyst production were recorded (Montresor et al. 1998). Some cyst morphotypes are produced almost uninterruptedly throughout the year, while others are produced over more restricted periods. Dinoflagellate cyst production is very low during winter, when motile stages are also very scarce, while maximum cyst production occurs in early spring and late summerautumn. The abundance and composition of the cyst assemblage produced over the annual cycle is apparently unrelated to in situ nutrient concentration, which is often invoked as a trigger of sexual reproduction and the consequent formation of resting cysts in dinoflagellates (Pfiester \& Anderson 1987). Nutrient depletion is in fact used in laboratory manipulations to induce the production of resting stages, but there is no evidence 
that nutrient limitation has an effect in situ (Anderson 1998, Kremp \& Heiskanen 1999). Encystment is a complex phenomenon in which the physiological responses of the vegetative population are modulated by more than one environmental factor. Temperature and daylength, together with nutrient availability, regulate phytoplankton growth, but they also act as environmental signals for the onset of specific changes in the organism's life cycle. Low temperature and a short day may accelerate diatom resting-cell formation (SickoGoad et al. 1989). Different combinations of temperature and daylength influence germination time in diatom resting spores (McQuoid \& Hobson 1995), and photoperiod has been advocated to be the main environmental trigger in diatom spore germination (Eilertsen et al. 1995). Studies on dinoflagellate cyst formation have demonstrated that encystment usually takes place within a specific temperature window (Anderson et al. 1984, 1985) whereas, to our knowledge, there are no data on the effect of daylength on the encystment process.

We tested the role of temperature and daylength on the formation of resting stages in 4 calcareous cystproducing dinoflagellate species from the Gulf of Naples. Experiments were carried out with batch cultures, using growth media with various nutrient concentrations and, for Scrippsiella rotunda, with semicontinuous cultures in which nutrient concentration was kept within values comparable to in situ concentrations.

\section{MATERIALS AND METHODS}

Cultures. The cultures of Scrippsiella trochoidea var. aciculifera (SZN 60), Pentapharsodinium tyrrhenicum (SZN 21 and SZN 23), Calciodinellum operosum (SZN 74) and S. rotunda (SZN 78) were obtained from the germination of resting cysts collected in the Gulf of Naples. S. trochoidea var. aciculifera cysts and vegetative cells are undistinguishable from those of the nominal species $S$. trochoidea, the only difference being the presence of a small acicular process on the internal side of the sulcal area in the variety aciculifera (D'Onofrio et al. 1999). Upon germination, a single cell was isolated with a micropipette and a clonal culture was established. Culture stocks were maintained in glass test tubes filled with $30 \mathrm{ml}$ of $\mathrm{K}$ growth medium (Keller et al. 1987) without silica, prepared with oligotrophic Mediterranean seawater adjusted to a salinity of 36 psu by the addition of sterile bi-distilled water. Cultures were grown at $20^{\circ} \mathrm{C}$, a photon-flux density of about $100 \mu \mathrm{mol}$ photons $\mathrm{m}^{-2}$ $\mathrm{s}^{-1}$, and a photoperiod of 12:12 h light:dark (12L:12D) cycle.
Scrippsiella trochoidea var. aciculifera, Calciodinellum operosum, and $S$. rotunda are homothallic species, i.e. able to produce cysts within a single clone, while Pentapharsodinium tyrrhenicum produces cysts only when 2 different clones (SZN 21 and SZN 23) are mixed.

Encystment experiments: batch cultures. Cyst production was tested under 18 combinations of temperatures $\left(15,20\right.$, and $\left.25^{\circ} \mathrm{C}\right)$, daylength $(8,12,16 \mathrm{~h}$ of light) and culture medium concentrations (K/5 and K/50). Cyst production in the full-strength $\mathrm{K}$ medium was not tested, because no cyst production was recorded during preliminary experiments with this medium. The temperatures used cover the ranges recorded in the surface ( 0 to $10 \mathrm{~m}$ ) coastal waters of the Gulf of Naples, where minimum temperatures occur in March (average monthly value: $13.98^{\circ} \mathrm{C}$ ) and maximum temperatures in August (average monthly value: $25.38^{\circ} \mathrm{C}$ ) (data calculated over the period 1984 to 1990; M. Ribera d'Alcala' pers. comm.). The hours of light reflect the range recorded during the year at this latitude. A stock of offshore oligotrophic seawater was filtered through $0.45 \mu \mathrm{m}$ pore-sized Millipore filters, adjusted to a salinity of 36 psu by the addition of sterile bi-distilled water, and stored in the dark at a temperature of about $15^{\circ} \mathrm{C}$. This stock was used to prepare the growth media (K/5 and K/50) used for all experiments. Cultures were not axenic, but examination of the culture stock under a light microscope $(1000 \times)$ before inoculation showed that the bacteria concentration was very low. Before running the experiments, cultures were acclimatized at the different temperatures and photoperiods for about 2 wk. Exponentially growing cells were inoculated in $250 \mathrm{ml}$ plastic tissue culture flasks filled with $150 \mathrm{ml}$ of growth medium, to reach a final concentration of 100 cells ml ${ }^{-1}$. Duplicate flasks were prepared for each experimental setting. Experiments were carried out in Heraeus growth chambers at a controlled temperature $\left( \pm 0.5^{\circ} \mathrm{C}\right)$ and illumination $(170 \mu \mathrm{mol}$ photons $\mathrm{m}^{-2} \mathrm{~s}^{-1}$ ) provided by cool-white fluorescent tubes placed above the shelves. Photon-flux density was measured as photosynthetically available radiation (400 to $700 \mathrm{~nm}$ ) with a spherical quantum sensor (LiCor) placed close to the culture flasks. The experiments were run for $3 \mathrm{wk}_{\text {; }}$ cell and cyst concentrations were monitored every second day during the first $2 \mathrm{wk}$ and at the end of the third week of incubation. For cell and cyst enumeration, $3 \mathrm{ml}$ of culture were subsampled, after gentle agitation of the flask, at the same time of day, and fixed with $\mathrm{NaCO}_{3}$-neutralized formaldehyde. Duplicate counts were made at a Zeiss Axiophot microscope using a $1 \mathrm{ml}$ Sedgwick-Rafter slide. Encystment percentage was calculated as $2 \cdot \mathrm{n}$ cysts $\cdot(\mathrm{n}$ cells $+2 \cdot \mathrm{n}$ cysts $)^{-1}$, where ' $n$ cysts' is the maximum cyst concentration and 'n cells' is the corresponding concentration 
of vegetative cells. This formula is based on the assumption that resting cysts are the result of a conjugation process between 2 vegetative cells (functional gametes). Exponential specific growth rates $\left(\mathrm{d}^{-1}\right)$ were calculated from the regression of ln-transformed cell concentration data over time intervals ranging from 5 to $8 \mathrm{~d}$; cell division rates (div. $\mathrm{d}^{-1}$ ) were obtained by dividing the specific growth rates by $\ln 2$.

To rule out that reduced total daily irradiance played a role in the higher encystment percentages recorded at the shortest daylength, additional experiments were carried out at a 16L:8D cycle, with a photon-fluence density $\left(85 \mu \mathrm{mol}\right.$ photons $\mathrm{m}^{-2} \mathrm{~s}^{-1}$ ) that provides the same total daily irradiance as in the experiments at a 8L:16D cycle. A control experiment was run at the photon-flux density used for the other experiments $\left(170 \mu \mathrm{mol}\right.$ photons $\left.\mathrm{m}^{-2} \mathrm{~s}^{-1}\right)$ at a $8 \mathrm{~L}: 16 \mathrm{D}$ cycle. These experiments were run with Scrippsiella trochoidea var. aciculifera, Calciodinellum operosum, and S. rotunda at $25^{\circ} \mathrm{C}$. We could not test Pentapharsodinium tyrrhenicum because we lost Culture SZN 21. Experiments were run with $\mathrm{K} / 50$ culture medium according to the protocol described above.

Statistical significance of the effect of the 2 media (K/5 and K/50) on cyst production was determined by the Kruskal-Wallis test (Sokal \& Rohlf 1995).

Experiments with semi-continuous cultures of Scrippsiella rotunda. An additional set of experiments was conducted to test cyst production in S. rotunda using semi-continuous cultures in order to decouple the effect of daylength from that of nutrient starvation. Experiments were run for 19 to $23 \mathrm{~d}$ in Heraeus growth chambers at a temperature of $20^{\circ} \mathrm{C}$ and at a photonflux density of $170 \mu \mathrm{mol}$ photons $\mathrm{m}^{-2} \mathrm{~s}^{-1}$ provided by cool-white fluorescent tubes. We used a slightly modified K/50 medium prepared with oligotrophic seawater. The stock of seawater was pre-filtered through $0.45 \mu \mathrm{m}$ pore-sized Millipore filters, sterilized by filtration through sterile $0.22 \mu \mathrm{m}$ pore-sized filtration units, adjusted to a salinity of 36 psu by the addition of sterile bi-distilled water, and stored in sterile polycarbonate containers in the dark. The medium was prepared as in Keller et al. (1987) by adding sterilized macro- and micronutrients and vitamins. The growth medium contained 0.9 to $1.15 \mu \mathrm{mol} \mathrm{l}^{-1}$ phosphate, 9.16 to $12.17 \mu \mathrm{mol} \mathrm{l}^{-1}$ nitrate, and 1.03 to $1.45 \mu \mathrm{mol} \mathrm{l^{-1 }}$ ammonia; all the other elements were in K/50 ratios. Nutrient concentrations were in the highest ranges recorded in coastal areas of the Gulf of Naples during the summer months (Zingone et al. 1990). Three replicate $300 \mathrm{ml}$ tissue-culture flasks were filled with $200 \mathrm{ml}$ of modified K/50 medium and inoculated with $S$. rotunda cells at a final concentration of 500 cells $\mathrm{ml}^{-1}$. To avoid nutrient enrichment from the inoculum, exponentially growing cultures were gently concen- trated on a sterile filtration system equipped with a $10 \mu \mathrm{m}$ mesh-sized phytoplankton net, and resuspended in sterile seawater. To maintain cultures in a stationary growth phase, flasks were diluted every second day. At the same hour of the day, flasks were gently agitated, a $2 \mathrm{ml}$ subsample was fixed with $\mathrm{NaCO}_{3}$-neutralized formol, and cell and cyst concentrations were estimated in a Sedgwick-Rafter counting chamber. Based on cell concentrations, a fraction of culture was withdrawn after gentle agitation of the flask, and the remaining cell suspension was diluted with fresh growth medium so as to maintain a cell density of 500 cells $\mathrm{ml}^{-1}$. The periodical dilution factors, i.e. the number of cysts present in the volume of culture that was removed, were adjusted for in the calculation of the total cyst concentration.

Experiments were carried out at the following L:D cycles: 8:16 h, 10:14 h, 11:13 h, 12:12 h, and 16:8 h. An experiment at a 12L:12D cycle was run with a total daily amount of photon flux equal to that supplied in the 8L:16D photoperiod experiment (12L:12D dim). Two more experiments were conducted to test the effect of a light break in the middle of the long dark phase. The first experiment was run at a cycle of 8L:7D:2L:7D, with a photon-flux density of $170 \mu \mathrm{mol}$ photons $\mathrm{m}^{-2} \mathrm{~s}^{-1}$. The second experiment was run at a cycle of 8L:7.5D:1L:7.5D; during the $8 \mathrm{~h} \mathrm{~L}$ period, a photon-flux density of $170 \mu \mathrm{mol}$ photons $\mathrm{m}^{-2} \mathrm{~s}^{-1}$ was provided and, during the $1 \mathrm{~h}$ light break, a lower photon flux density of $30 \mu \mathrm{mol}$ photons $\mathrm{m}^{-2} \mathrm{~s}^{-1}$, which represents the growth-limiting photon-flux density for Scrippsiella rotunda.

Nitrate, ammonium and phosphate concentrations in the growth medium were estimated on duplicate samples with a Technicon AutoAnalyzer II (Grasshoff et al. 1983). In a preliminary experiment run for $10 \mathrm{~d}$ at a 12L:12D cycle, nutrient concentrations were measured every second day, before and after dilution, to test the range of variation of nutrient concentrations. In all other experiments, nutrient concentrations were estimated at the beginning of the experiment and 2 or 3 times thereafter. To estimate the physiological status of the cultures, the intracellular pool of carbon and nitrogen was estimated at the beginning and at the end of the experiments. Three to 6 replicate samples containing $10^{3}$ to $10^{4}$ cells were filtered on pre-combusted Whatman GF/C filters, which were exposed for 8 to $12 \mathrm{~h}$ to $\mathrm{HCl}$ fumes. Samples were analyzed with an Elemental Analyzer Carlo Erba EA 1108. The decrease in $\mathrm{pH}$ values could dissolve the calcareous layer that surrounds the cysts; the pH of algal cultures was thus measured during the light and the dark phase and before and after dilution. Growth rates (div. $d^{-1}$ ) over the $2 \mathrm{~d}$ dilution intervals were calculated as described above. 


\section{RESULTS}

\section{Cyst production in batch cultures}

All strains grew under all the experimental conditions tested; maximum growth rates ranging from 0.27 to 1.0 and from 0.13 to $0.5 \mathrm{div}$. $\mathrm{d}^{-1}$ were recorded in the experiments with $\mathrm{K} / 5$ and with $\mathrm{K} / 50$ medium, respectively. In general, cyst formation started earlier at 20 and $25^{\circ} \mathrm{C}$ than at $15^{\circ} \mathrm{C}$ (Figs. $1 \& 2$ ). At $25^{\circ} \mathrm{C}$, on 2 occasions, cyst formation was recorded only at the end of the experiment (Calciodinellum operosum 12L:12D with K/5 and Scrippsiella rotunda 12L:12D with K/50). Under the remaining experimental conditions, the first cysts were found from the Days 6 to 15 (average value $=8.3, n=10$ ) and from the Days 4 to 8 (average value $=6.2, n=10$ ) in the experiments with $\mathrm{K} / 5$ and K/50, respectively. At $20^{\circ} \mathrm{C}$, cyst formation started between Days 6 and 15 (average value $=9.4, \mathrm{n}=7$ ) with $\mathrm{K} / 5$ medium and between Days 6 and 8 (average value $=7, \mathrm{n}=8$ ) with $\mathrm{K} / 50$ medium. At $15^{\circ} \mathrm{C}$, cysts were generally recorded towards the end of the experiment: between Days 15 and 21 with K/5 medium and between Days 10 and 15 (average value $=12.5, \mathrm{n}=6$ ) in the experiments with $\mathrm{K} / 50$. The onset of encystment was not related to a threshold concentration of vegetative cells with either medium. We could not trace putative planozygotes during the experiments because they were not recognizable in the fixed samples of any of the 4 species. Large cells (28 to $32 \mu \mathrm{m}$ in length) present in the cultures were at the upper limit of a unimodal size distribution and they were not characterized by a higher content of storage material.
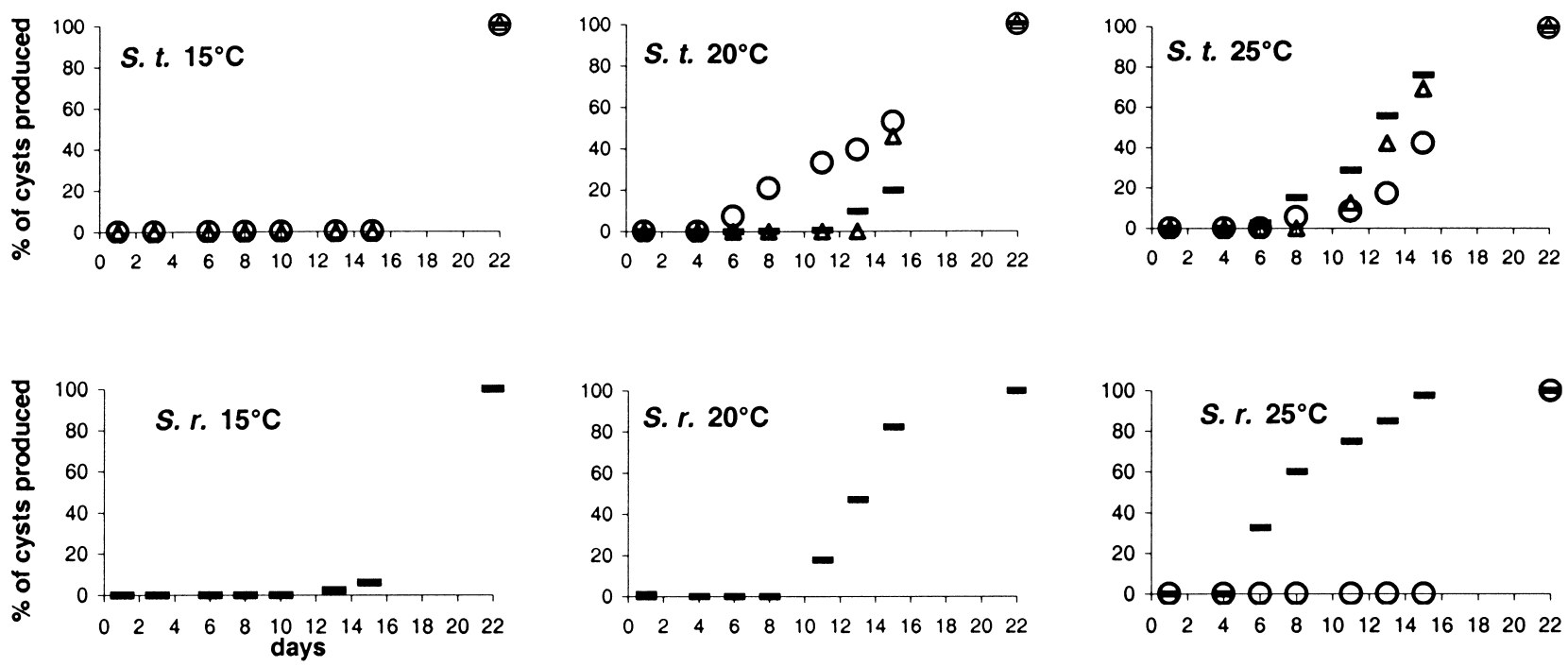

\begin{tabular}{|c|c|c|}
\hline $\begin{array}{l}\text { S. } t .=\text { Scrippsiella trochoidea var. } a c \\
\text { S. } r .=\text { Scrippsiella rotunda }\end{array}$ & & 8L:11 \\
\hline C.o. = Calciodinellum operosum & 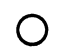 & $=12 \mathrm{~L}: 12$ \\
\hline P. $t .=$ Pentapharsodinium tyrrhenicum & $\Delta$ & $=16 \mathrm{~L}: 8$ \\
\hline
\end{tabular}

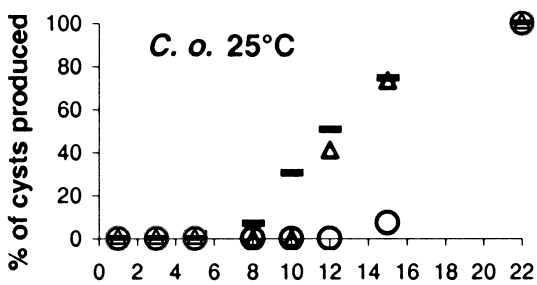

Fig. 1. Scrippsiella trochoidea var. aciculifera, Pentapharsodinium tyrrhenicum, Calciodinellum operosum, and S. rotunda. Encystment time-course, expressed as percentage of cysts produced over time (d), relative to the batch-culture experiments in K/5 growth medium; only data relative to the experimental conditions in which cyst formation was observed are shown
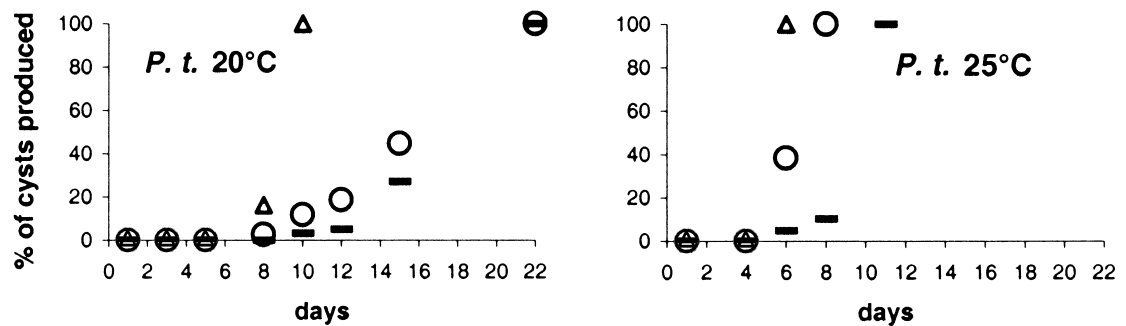
Scrippsiella trochoidea var. aciculifera in K/5 medium produced cysts under all the experimental conditions, with the exception of the shortest daylength conditions at $15^{\circ} \mathrm{C}$ (Fig. 3a). Large numbers of cysts were recorded at $20^{\circ} \mathrm{C}, 8 \mathrm{~L}: 16 \mathrm{D}$ (up to 792 cysts $\mathrm{ml}^{-1}$ ); otherwise, cyst production was between 7 and 109 cysts $\mathrm{ml}^{-1}$. Pentapharsodinium tyrrhenicum formed cysts (12 to 104 cysts $\mathrm{ml}^{-1}$ ) only at 20 and $25^{\circ} \mathrm{C}$ (Fig. 3b). Toward the end of the experiments, the calcareous layer surrounding the $P$. tyrrhenicum cysts had dissolved in all culture flasks kept at $25^{\circ} \mathrm{C}$ and in those kept at $20^{\circ} \mathrm{C}$ at the longest light cycle. Calciodinellum operosum pro- duced cysts ( 6 to 60 cells $\mathrm{ml}^{-1}$ ) only at $25^{\circ} \mathrm{C}$ (Fig. 3c). $S$. rotunda produced only very limited numbers of cysts at $15^{\circ} \mathrm{C}, 8 \mathrm{~L}: 16 \mathrm{D}$, at $20^{\circ} \mathrm{C}, 8 \mathrm{~L}: 16 \mathrm{D}$ and at $25^{\circ} \mathrm{C}$ with 8 and $12 \mathrm{~h}$ of light (Fig. 3d). Encystment percentages were relatively low (from 0 to $23 \%$ ) in all experiments in $\mathrm{K} / 5$ medium.

In the experiments with K/50 medium, encystment patterns were essentially the same as those with K/5 medium (Fig. 4). However, both the number of cysts produced $(p=0.016)$ and the encystment percentages ( $p \leq 0.001)$ were significantly higher. In all 4 species, encystment percentage was inversely related with
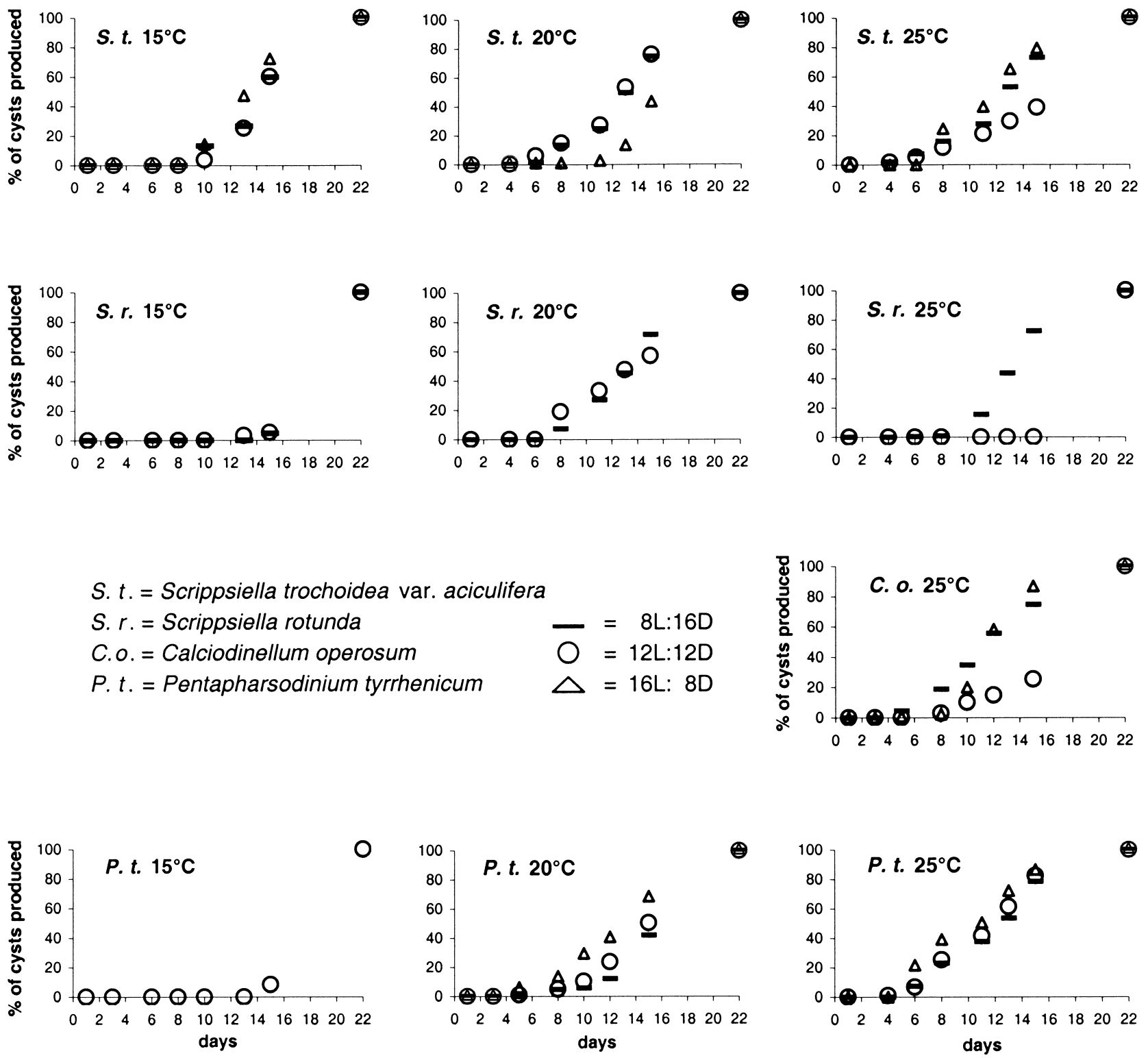

Fig. 2. Scrippsiella trochoidea var. aciculifera, Pentapharsodinium tyrrhenicum, Calciodinellum operosum, and S. rotunda. Encystment time-course, expressed as percentage of cysts produced over time (days), relative to the batch-culture experiments in $\mathrm{K} / 50$ growth medium. Only data relative to the experimental conditions in which cyst formation was observed are shown 


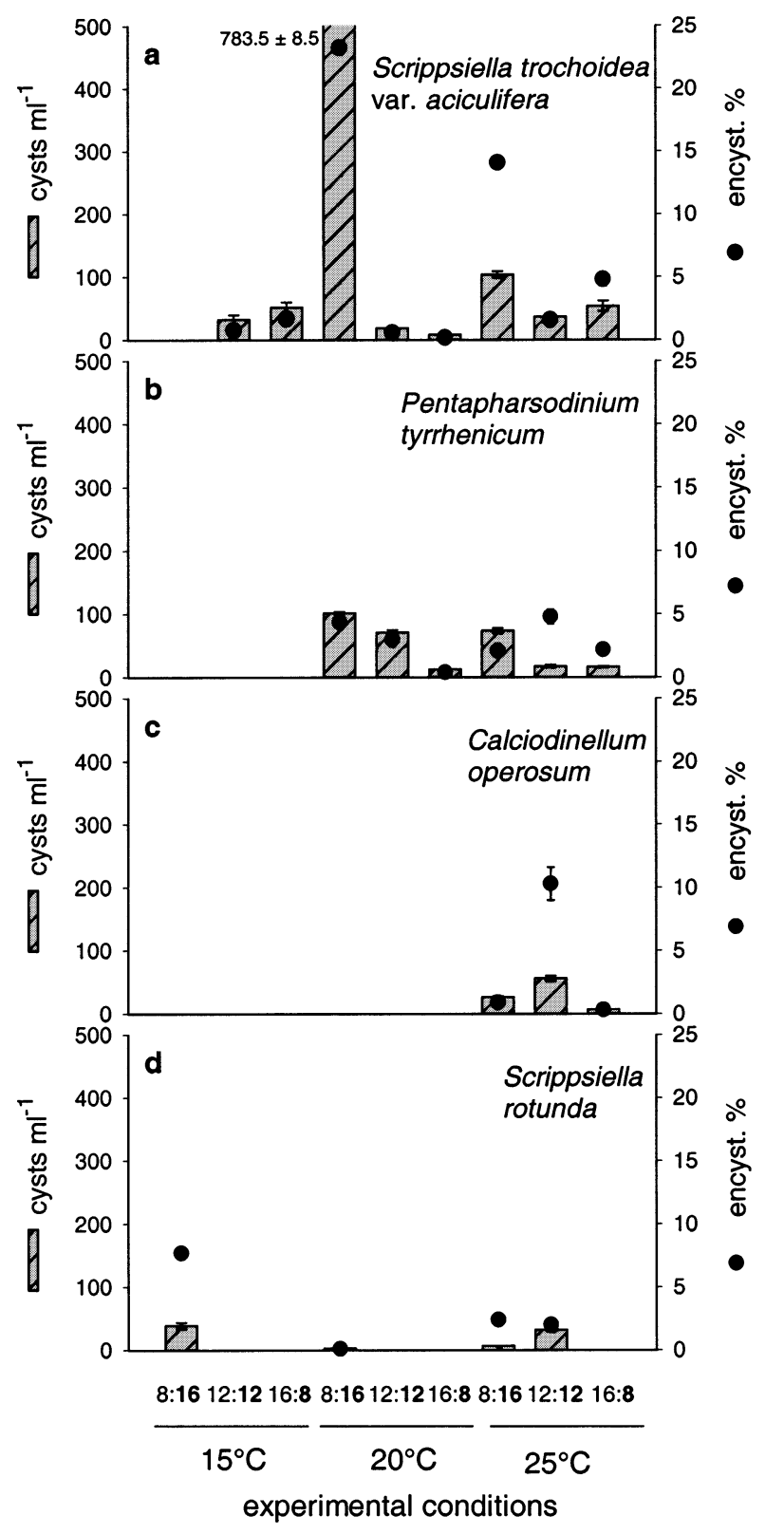

Fig. 3. (a) Scrippsiella trochoidea var. aciculifera, (b) Pentapharsodinium tyrrhenicum, (c) Calciodinellum operosum and (d) S. rotunda. Maximum cyst concentration (bars) and maximum encystment percentage $(\bullet)$ in batch-culture experiments with K/5 medium, at different temperature and daylength ( $h$, abscissa) conditions. Data are average value of the 2 replicates, represented by vertical lines

daylength at 20 and $25^{\circ} \mathrm{C}$. Scrippsiella rotunda showed a massive encystment $(>90 \%)$ at the shortest daylength $(8 \mathrm{~h})$ at both 20 and $25^{\circ} \mathrm{C}$ (Fig. $4 \mathrm{~d}$ ).

In the additional experiments run at a $16 \mathrm{~L}: 8 \mathrm{D}$ cycle but with the same amount of total daily irradiance (4.9 mol photons $\mathrm{m}^{-2} \mathrm{~d}^{-1}$ ) as provided in the short-day conditions (8L:16D cycle), the percentage of encyst-

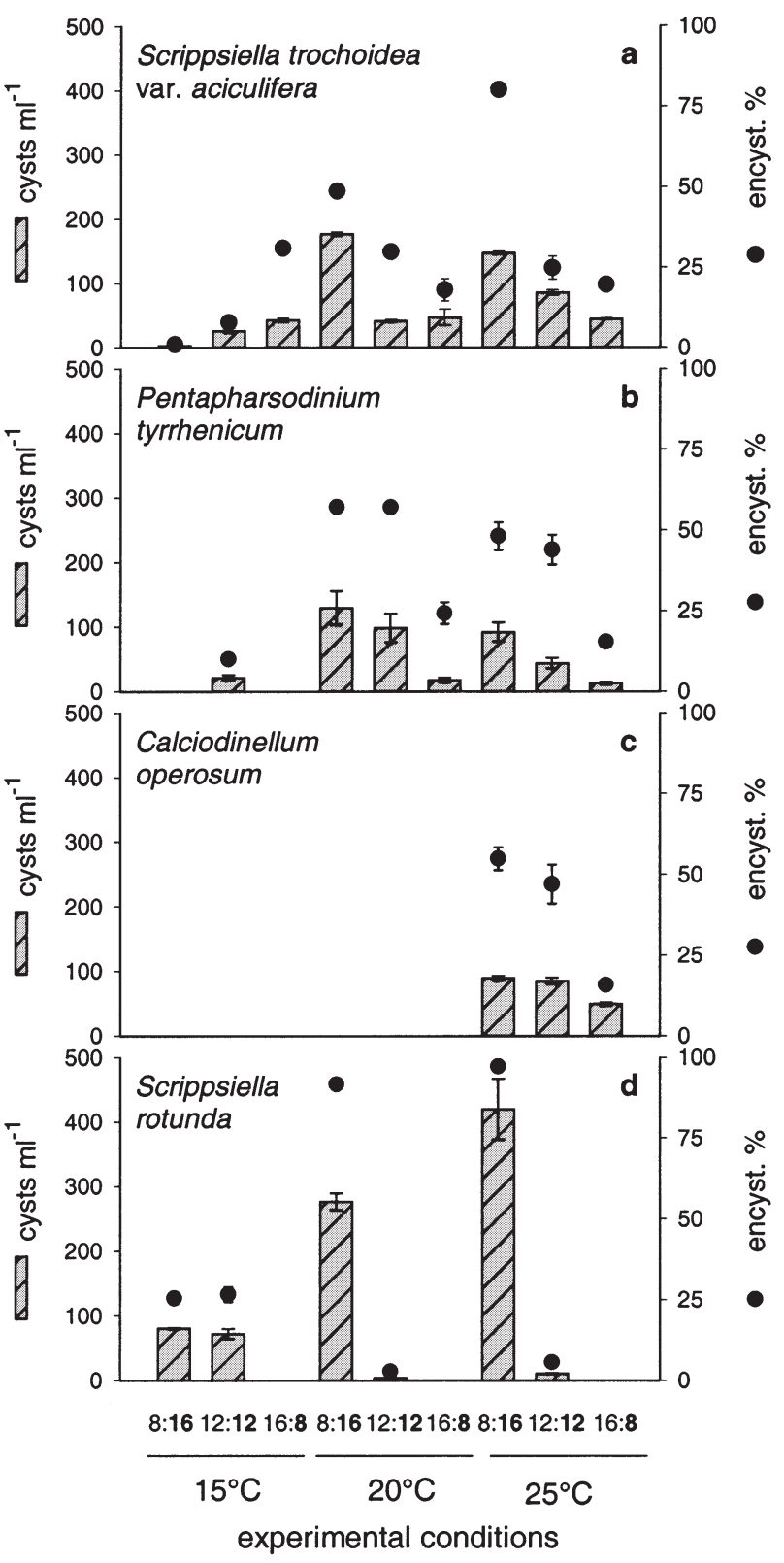

Fig. 4. (a) Scrippsiella trochoidea var. aciculifera, (b) Pentapharsodinium tyrrhenicum, (c) Calciodinellum operosum and (d) S. rotunda. Maximum cyst concentration (bars) and maximum encystment percentage $(\bullet)$ in batch-culture experiments with K/50 medium at different temperature and daylength ( $h$, abscissa) conditions. Data are average values of the 2 replicates, represented by vertical lines. Note the different scale for encystment percentage from that in Fig. 3

ment in the 3 cultures was comparable to that obtained in the experiments at a 16L:8D cycle with a higher daily irradiance (9.79 mol photons $\mathrm{m}^{-2} \mathrm{~d}^{-1}$ ) (Fig. 5). This confirms that daylength, and not the total amount of daily irradiance, plays a prominent role in controlling cyst formation. 


\section{Experiments with semi-continuous cultures of Scrippsiella rotunda}

In semi-continuous cultures of Scrippsiella rotunda, cyst formation occurred only at the shortest daylengths: mean cyst concentrations of 80.3 and 32.8 cysts ml $\mathrm{m}^{-1}$ were recorded at 8 and $10 \mathrm{~h}$ of light, respectively, while an extremely low cyst concentration (1.2 cysts $\mathrm{ml}^{-1}$ ) was recorded at $11 \mathrm{~h}$ of light (Table 1). At 8L:16D, the production of resting cysts started at Day 9, and cyst concentration at the end of the experiment ranged between 81 and 95.5 cysts ml ${ }^{-1}$. At a 10L:14D cycle, cyst production started on Day 12, with cyst concentrations between 28 and 36 cysts $\mathrm{ml}^{-1}$. No cysts were

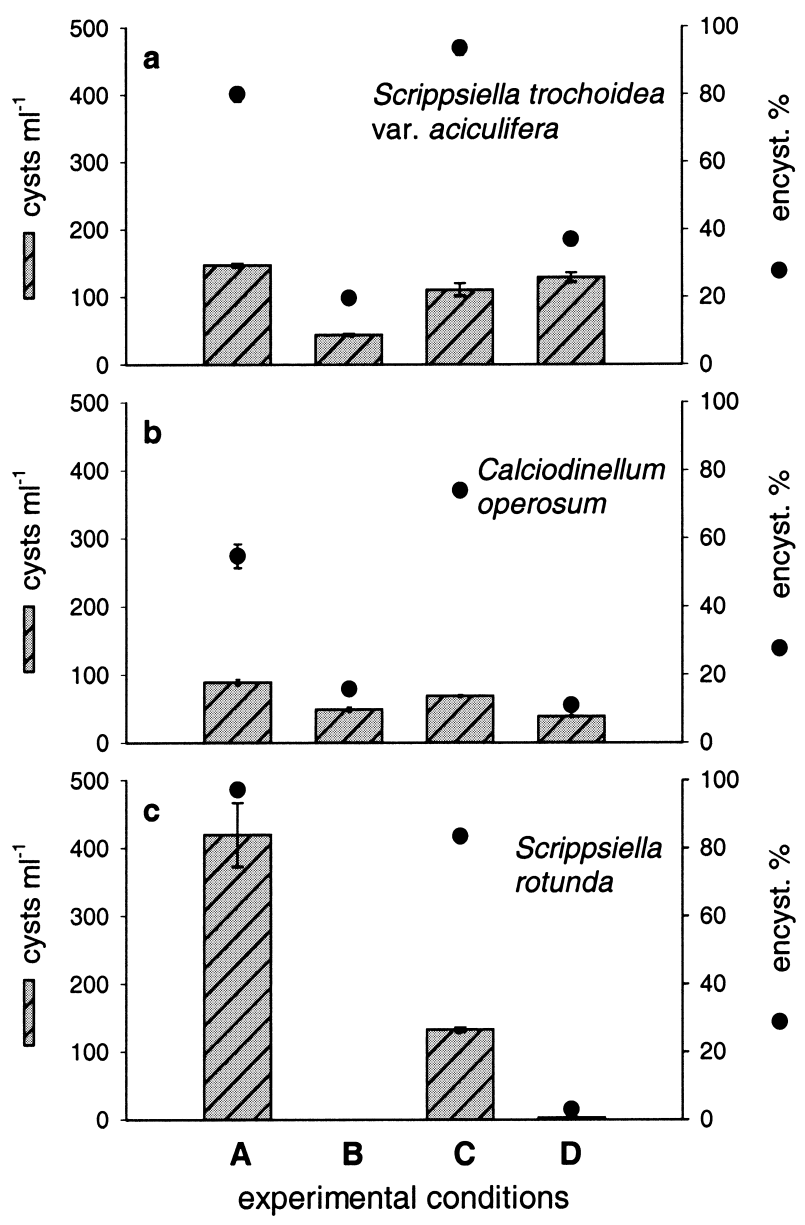

Fig. 5. (a) Scrippsiella trochoidea var. aciculifera, (b) Calciodinellum operosum, and (c) $S$. rotunda. Maximum cyst concentration (bars) and maximum encystment percentage $(\bullet)$ in batch-culture experiments with $\mathrm{K} / 50$ medium at $25^{\circ} \mathrm{C}$. Data are average value of the 2 replicates, represented by vertical lines. Experiments A (8:16 h L:D) and B (16:8 h L:D) were the same as in Fig. 4; Expt $\mathrm{C}$ was the control test (same conditions as in A); Expt D (16:8 h L:D) had a lower photon fluence rate (85 $\mu \mathrm{mol}$ photons $\mathrm{m}^{-2} \mathrm{~s}^{-1}$ ) that provided the same total daily irradiance as in Expt $\mathrm{C}$ but over a longer daylength formed when the same total irradiance supplied at an 8L:16D cycle (4.9 mol photons $\mathrm{m}^{-2} \mathrm{~d}^{-1}$ ) was supplied over a 12L:12D cycle. Cyst formation was suppressed also when the dark period was interrupted by light breaks of various lengths and intensities, even if the overall duration of light was the same as in cyst-inducing conditions (Table 1).

Mean growth rates calculated over the $2 \mathrm{~d}$ dilution intervals increased with the length of the light phase, up to $12 \mathrm{~h}$ of light, then they decreased at the longest daylength (16 h of light) (Table 1$)$. The very low standard deviation values indicate that cultures were growing at a constant rate during the experiment. Nutrient limitation was never detected in the culture medium before diluting the cultures. After dilution with fresh growth medium, nutrient concentrations ranged between 11.12 and $8.06 \mu \mathrm{mol} \mathrm{l^{-1 }}$ for nitrate, 1 and $0.49 \mu \mathrm{mol} \mathrm{l}^{-1}$ for ammonium, and 0.88 and $0.21 \mu \mathrm{mol} \mathrm{l}^{-1}$ for phosphate. The intracellular $\mathrm{C}: \mathrm{N}$ molar ratio in the culture stocks at the beginning of the experiments was between 9.1 and 16.2 (Table 1). The higher values measured at the beginning of the experiment at 8L:16D and at 16L:8D were due to a delay in the analysis: culture subsamples were kept in filtered seawater for 2 more days after the beginning of the experiment, thus causing nitrogen depletion. $\mathrm{C}: \mathrm{N}$ values at the end of the experiments were between 6.6 and 9.3 (Table 1). For thecate dinoflagellates, $\mathrm{C}: \mathrm{N}$ ratios higher (up to 8-10) than the Redfield ratio (6.6) are usually reported; our data thus suggest that Scrippsiella rotunda cells were not nitrogen-depleted. $\mathrm{pH}$ values were constant, ranging between 7.98 and 8.08 .

\section{DISCUSSION}

Our data suggest that encystment in the 4 calcareous cyst-forming species studied is regulated by a complex interplay of at least 3 factors: daylength, temperature and nutrient concentration.

An inverse relationship between encystment percentage and daylength was observed at 20 and $25^{\circ} \mathrm{C}$ for all the species in the experiments carried out with batch cultures. In Scrippsiella trochoidea var. aciculifera, Pentapharsodinium tyrrhenicum, and Calciodinellum operosum encystment is enhanced by short daylength conditions; however, these species produced cysts also at the longest daylengths. In contrast, in $S$. rotunda, encystment was never observed at the longest daylength. Our experiments with semi-continuous cultures suggest that cyst formation in this species may be daylength-controlled. In fact, cyst production occurred only at the shortest daylengths, it was not the result of a reduced total daily irradiance, and it was prevented by light breaks during the dark phase of the photo- 
Table 1. Scrippsiella rotunda. Experiments with semi-continuous cultures at different light:dark (L:D) cycles: daily photon flux $\left(\mathrm{mol}\right.$ photons $\left.\mathrm{m}^{-2} \mathrm{~d}^{-1}\right)$ under the different experimental conditions, mean $( \pm \mathrm{SD})$ cyst concentration at the end of the experiment $\left(\right.$ cysts $\left.\mathrm{ml}^{-1}\right)$, mean $( \pm \mathrm{SD}) \mathrm{C}: \mathrm{N}$ molar ratios at the beginning $(\mathrm{C}: \mathrm{N}$ beginning) and at the end $(\mathrm{C}: \mathrm{N}$ end $)$ of the experiment, and mean $( \pm \mathrm{SD})$ growth rates (divisions $\mathrm{d}^{-1}$ ) over the $2 \mathrm{~d}$ dilution intervals. $\mathrm{n}$ : number of replicate samples

\begin{tabular}{|lccrrr|}
\hline $\begin{array}{c}\text { L:D cycles } \\
(\mathrm{h})\end{array}$ & $\begin{array}{c}\text { Daily photon flux } \\
\left(\mathrm{mol} \text { photons } \mathrm{m}^{-2} \mathrm{~d}^{-1}\right)\end{array}$ & $\begin{array}{c}\text { Cysts ml } \\
(\mathrm{n}=3)\end{array}$ & \multicolumn{2}{c|}{$\begin{array}{c}\text { C:N }( \pm \mathrm{SD}) \text { at: } \\
\text { Beginning }\end{array}$} & End \\
\hline 8L:16D & 4.90 & $80.3(15.7)$ & $16.2(1.12), \mathrm{n}=4$ & $9.3(0.97), \mathrm{n}=3$ & $0.42( \pm 0.16)$ \\
10L:14D & 6.12 & $32.8(4.1)$ & $9.1(1.13), \mathrm{n}=4$ & $6.6(0.86), \mathrm{n}=6$ & $0.62( \pm 0.15)$ \\
11L:13D & 6.73 & 1.2 & $9.1(1.13), \mathrm{n}=4$ & $6.9(1.21), \mathrm{n}=6$ & $0.63( \pm 0.10)$ \\
12L:12D & 7.34 & 0 & $9.1(1.13), \mathrm{n}=4$ & $6.9(0.56), \mathrm{n}=6$ & $0.78( \pm 0.11)$ \\
16L:8D & 9.79 & 0 & $16.2(1.12), \mathrm{n}=4$ & $7.8(0.26), \mathrm{n}=3$ & $0.52( \pm 0.11)$ \\
12L:12D (dim) & 4.90 & 0 & $10.8(0.23), \mathrm{n}=4$ & $7.1(0.09), \mathrm{n}=6$ & $0.68( \pm 0.13)$ \\
8L:7D:2L:7D & 6.12 & 0 & $9.1(1.13), \mathrm{n}=3$ & $6.7(1.19), \mathrm{n}=6$ & $0.58( \pm 0.08)$ \\
8L:7.5D:1L:7.5D & 5.00 & 0 & $10.8(0.23), \mathrm{n}=3$ & $7.95(0.30), \mathrm{n}=6$ & $0.48( \pm 0.10)$ \\
\hline
\end{tabular}

cycle. According to Dring (1984), a photoperiodic response implies that the 'timing' of light and darkness in the $24 \mathrm{~h}$ cycle, and not the total amount of light has an effect on some aspects of the organism life cycle. We tested this hypothesis with batch cultures of $S$. trochoidea var. aciculifera, C. operosum and S. rotunda, and with semi-continuous cultures of $S$. rotunda. Long daylength completely inhibited cyst production by $S$. rotunda. Short-day photoperiodic responses are inhibited by a light-break during the dark phase (Dring 1984), and our results with $S$. rotunda confirm that cyst formation may be regulated by a photoperiodic-sensitive mechanism. Daylength has been shown to govern shifts from the motile flagellate stage to a temporary cyst in the dinoflagellate Lingulodinium polyedrum (=Gonyaulax polyedra) (Balzer \& Hardeland 1991), and development and life history phase of macroalgae change depending on daylength (Dring 1984, 1988). Daylength has been shown to influence sexual reproduction of the diatom Pseudo-nitzschia multiseries, for which a positive correlation was found between gamete production and hours of light exposure per $24 \mathrm{~h}$ (Hiltz et al. 2000). Hiltz et al. speculate that a longer exposure to light would allow a higher allocation of the photosynthetic energy to gametogenesis, thus resulting in a greater production of zygotes and auxospores. However, in the 4 dinoflagellate species we tested, cyst production was inversely related to daylength. Consequently, the explanation of Hiltz et al. does not apply to the encystment process in these dinoflagellates. Although very little information is available about the physiological effects of different daylengths on the physiology of phytoplanktonic organisms, there is evidence that the metabolic machinery runs differently under a photoperiodic regime than under continuous light conditions (e.g. Burkhardt et al. 1999). It is thus reasonable to argue that differences in the length of the light or dark phase could further modulate metabolic processes which, in turn, could act as induction mechanisms for the encystment process. However, we may also speculate that the length of the light or dark phase could be perceived by phytoplankton species, e.g. through phytochrome- or cryptochrome-like receptors, and that short daylength conditions could signal the approach of unfavourable conditions related to winter and thus activate the metabolic pathways leading to cyst formation.

The 4 calcareous cyst-forming dinoflagellate species of our study showed distinct encystment patterns in batch cultures at different temperatures. This reflects the existence of species-specific temperature windows under which encystment can occur, which are more restricted than the temperature ranges for vegetative reproduction (Anderson et al. 1984, 1985). In Lingulodinium polyedrum, the shift from motile cells to temporary cysts is under strict photoperiodic control at $15^{\circ} \mathrm{C}$, while no cysts are formed at $20^{\circ} \mathrm{C}$ (Balzer \& Hardeland 1991). Temperature may thus block or modify the response to daylength, and examples of restricted temperature windows for photoperiodic responses can be found in macroalgae (Dring 1984) and higher plants. The different relationships between cyst production and daylength observed for Scrippsiella trochoidea var. aciculifera and $S$. rotunda at $15^{\circ} \mathrm{C}$ compared with those at 20 and $25^{\circ} \mathrm{C}$ could indicate that low temperature alters the daylength-mediated response.

Cyst production was recorded only at specific temperature and daylength conditions, which were very similar in the experiments carried out with 2 different growth media. This indicates that nutrient limitation, which reasonably occurred within a few days in batchcultures with K/50 medium, does not represent a primary factor for encystment, since it was not able to induce cyst formation under temperature and daylength conditions unfavourable for encystment. Conversely, cyst production occurred at the shortest daylengths in semi-continuous cultures of Scrippsiella rotunda, for which nutrients were not limiting and veg- 
etative cells were not nutrient-depleted. Consequently, we suggest that the main factors regulating cyst production in these species are daylength and temperature, while nutrient concentration modulates the 'intensity' of this response. Encystment was recorded at relatively low nutrient concentrations comparable with those found under field conditions (Zingone et al. 1990); it was enhanced in nutrient-depleted growth media, and absent at the very high nutrient concentrations present in full-strength growth media (i.e. full-strength K medium; data not shown). Nitrate concentration affects photoperiodic responses in macroalgae: high nutrient concentrations inhibit the production of tetrasporangia under optimal photoperiod and temperature conditions, whereas reduced nutrient concentrations stimulate the expression of photoperiodic responses (Dring 1984). A complex interplay between nutrient concentrations and circadian rhythms has been reported for Lingulodinium polyedrum (= Gonyaulax polyedra: Roenneberg 1996, Roenneberg \& Rehman 1996), whereby several physiological activities (e.g. photosynthesis, bioluminescence, mitosis) are controlled by a circadian clock entrained by receptors with different spectral sensitivities (Roenneberg 1996). In this dinoflagellate, nitrate concentration acts as a non-photic signal for the circadian system, thereby shifting the phase of the circadian clock (Sweeney \& Folli 1984, Roenneberg \& Rehman 1996).

Cyst production at sea depends on the abundance of vegetative stages in the water column, which is in turn regulated by the balance of 'bottom-up' and 'topdown' constraints. A threshold cell concentration is required for a minimum encounter rate between gametes to produce the zygote, which then forms the cyst (Wyatt \& Jenkinson 1997). However, threshold cell concentration alone is not sufficient to explain cyst formation. Cell concentrations were comparable under all the conditions tested, but cyst production occurred only under specific temperature and daylength conditions. Caution should be exercised in extrapolating the results of laboratory experiments to cyst production at sea, which is governed by many factors at a different scale and variability. However, our results coincide with the results of a study on cyst production in the Gulf of Naples (Montresor et al. 1998), where field data showed a relatively high production of Scrippsiella trochoidea-like cysts almost uninterruptedly from early spring till autumn. Accordingly, we now report that encystment for this species occurs over a wide set of temperatures and photoperiods. This feature, coupled with the short dormancy that characterizes both $S$. trochoidea (Binder \& Anderson 1987) and S. trochoidea var. aciculifera (Nuzzo \& Montresor 1999), indicates that this species has a high capability of shifting from motile to encysted stage.
This helps to explain the high success of S. trochoidea-like species in the neritic environment (Pierce \& Turner 1994, Karentz \& Smayda 1998, Montresor et al. 1998), where cyst storage in the sediments acts as a benthic reservoir of the vegetative population. The late summer-autumn peaks of calcareous cyst production recorded in the Gulf of Naples (Montresor et al. 1998), as well as the production peaks of Scrippsiella spp. cysts (mainly $S$. trochoidea) recorded in early autumn in a Japanese bay (Ishikawa \& Taniguchi 1996), suggest that decreasing daylength, coupled with still-warm temperature conditions exert a positive effect on the encystment process.

The in situ production of Pentapharsodinium tyrrhenicum cysts, mainly confined to late summer-autumn (Montresor et al. 1998), fits our experimental data that cyst production was restricted to higher temperatures and was positively influenced by decreasing daylengths. Calciodinellum operosum produced cysts only at the highest temperature under laboratory experiments: these cysts were rarely found in our study area, and, the few records were restricted to September and October (Montresor et al. 1998), when surface temperatures range between 22 and $25^{\circ} \mathrm{C}$. These cysts are commonly found in tropical oceans (Dale 1992, Höll et al. 1998, 1999) where surface temperatures are high throughout the year.

Some of our laboratory findings are not supported by field data. This is the case for Scrippsiella rotunda, in which encystment was strictly related to short daylength conditions. This species produces the highest numbers of cysts in September and October, when daylength is short, but also in May and June, when daylength reaches the summer solstice maxima (Montresor et al. 1998). This could indicate that within the same morphospecies there are different ecotypes that produce resting stages under different environmental conditions. For example, an intraspecific variability in the circannual rhythm in cyst formation was reported for $S$. trochoidea, whereby only 3 out of 5 cultures from the same geographic area showed cyst production clearly timed in October to December, while 2 other clones showed several consecutive peaks of cyst production over the annual cycle (Costas \& Varela 1989). Other examples of strain-specific physiological variability are the differences in dormancy length reported for Alexandrium catenella isolated from different geographic areas (Hallegraeff et al. 1998), as well as differences in germination timing for $A$. tamarense populations along the USA coasts (Anderson 1997). The level of intraspecific diversity in phytoplanktonic species is still poorly known, but these examples suggest that intraspecific diversity may be another factor influencing the variability of cyst production patterns observed at sea. 
The results of our experiments suggest that daylength could be an environmental signal for the induction and/or modulation of cyst production in dinoflagellates. Light regulates several aspects of the life cycle and behavior of these organisms, i.e. physiological circadian rhythms (Roenneberg 1996), phototactic vertical migrations (Haeder \& Liu 1991, Kamykowski et al. 1998), and cyst germination (Binder \& Anderson 1986). Light quantity and quality, besides constituting the energy source for photosynthetic processes, can thus act as 'environmental messengers' that provide information about the temporal characteristics of the marine environment.

Acknowledgements. We thank Federico Corato and Maurizio Lorenti for their technical assistance. We are grateful to Jean Ann Gilder for editing the text.

\section{LITERATURE CITED}

Anderson DM (1997) Bloom dynamics of toxic Alexandrium species in the northwestern U.S. Limnol Oceanogr 42: 1009-1022

Anderson DM (1998) Physiology and bloom dynamics of toxic Alexandrium species, with emphasis on life cycle transitions. In: Anderson DM, Cembella AD, Hallegraeff GM (eds) Physiological ecology of harmful algal blooms. Springer-Verlag, Berlin, p 29-48

Anderson DM, Kulis DM, Binder BJ (1984) Sexuality and cyst formation in the dinoflagellate Gonyaulax tamarensis, cyst yield in batch cultures. J Phycol 20:418-425

Anderson DM, Coats DW, Tyler MA (1985) Encystment of the dinoflagellate Gyrodinium uncatenum, temperature and nutrient effects. J Phycol 21:200-206

Balzer I, Hardeland R (1991) Photoperiodism and effects of indoleamines in a unicellular alga, Gonyaulax polyedra. Science 253:795-797

Binder BJ, Anderson DM (1986) Green light-mediated photomorphogenesis in a dinoflagellate resting cyst. Nature 322:659-661

Binder BJ, Anderson DM (1987) Physiological and environmental control of germination in Scrippsiella trochoidea (Dinophyceae) resting cyst. J Phycol 23:99-107

Burkhardt S, Riebesell U, Zondervan I (1999) Stable carbon isotope fractionation by marine phytoplankton in response to daylength, growth rate, and $\mathrm{CO}_{2}$ availability. Mar Ecol Prog Ser 184:31-41

Costas E, Varela M (1989) A circannual rhythm in cyst formation and growth rates in the dinoflagellate Scrippsiella trochoidea Stein. Chronobiologia 16:265-270

Dale B (1992) Dinoflagellate contributions to the open ocean sediment flux. In: Dale B, Dale AL (eds) Dinoflagellate contributions to the deep sea. Woods Hole Oceanographic Institution, Woods Hole, MA, p 1-31 (Ocean Biocoenosis Series)

D'Onofrio G, Marino D, Bianco L, Busico E, Montresor M (1999) Toward an assessment on the taxonomy of dinoflagellate that produce calcareous cysts (Calciodinelloideae, Dinophyceae): a morphological and molecular approach. J Phycol 35:1063-1078

Dring MJ (1984) Photoperiodism and phycology. In: Round FE, Chapman DJ (eds) Progress in phycological research, Vol 3. Biopress, Bristol, p 159-192
Dring MJ (1988) Photocontrol of development in algae. Annu Rev Plant Physiol Plant Mol Biol 39:157-174

Eilertsen HCHR, Sandberg S, Tollefsen H (1995) Photoperiodic control of diatom spore growth: a theory to explain the onset of phytoplankton blooms. Mar Ecol Prog Ser 116: 303-307

Ellegaard M, Christensen NF, Moestrup O (1994) Dinoflagellate cysts from recent Danish marine sediments. Eur J Phycol 29:183-194

Grasshoff K, Erhardt M, Kremling K (1983) Methods of seawater analysis. Verlag Chemie, Weinheim

Haeder DP, Liu SM (1991) Biochemical isolation and spectroscopic characterization of possible photoreceptor pigments for phototaxis in a freshwater Peridinium. Photochem Photobiol 54:143-146

Hallegraeff GM, Marshall JA, Valentine J, Hardiman S (1998) Short cyst-dormancy period of an Australian isolate of the toxic dinoflagellate Alexandrium catenella. Mar Freshw Res 49:415-420

Hiltz M, Bates SS, Kacmarska I (2000) Effect of light:dark cycles and cell apical length on the sexual reprodution of the pennate diatom Pseudo-nitzschia multiseries (Bacillariophyceae) in culture. Phycologia 39:59-66

Höll C, Zonneveld KAF, Willems H (1998) On the ecology of calcareous dinoflagellates: the Quaternary eastern equatorial Atlantic. Mar Micropaleontol 33:1-25

Höll C, Karwath B, Rühlemann C, Zonneveld KAF, Willems H (1999) Palaeoenvironmental information gained from calcareous dinoflagellates: the late Quaternary eastern and western tropical Atlantic Ocean in comparison. Palaeogeogr Palaeoclimatol Palaeoecol 146:147-164

Ishikawa A, Taniguchi A (1996) Contribution of benthic cysts to the population dynamics of Scrippsiella spp. (Dinophyceae) in Onagawa Bay, northeast Japan. Mar Ecol Prog Ser 140:169-178

Kamykowski D, Milligan EJ, Reed RE (1998) Relationships between geotaxis/phototaxis and diel vertical migration in autotrophic dinoflagellates. J Plankton Res 20:1781-1796

Karentz D, Smayda TJ (1998) Temporal patterns and variations in phytoplankton community organization and abundance in Narragansett Bay during 1959-1980. J Plankton Res 20:145-168

Keller MD, Selvin RC, Claus W, Guillard RRL (1987) Media for the culture of oceanic ultraphytoplankton. J Phycol 23: 633-638

Keupp H (1991) Fossil calcareous dinoflagellate cysts. In: Riding $\mathrm{R}$ (ed) Calcareous algae and stromatolites. SpringerVerlag, Berlin, p 267-286

Kremp A, Heiskanen AS (1999) Sexuality and cyst formation of the spring-bloom dinoflagellate Scrippsiella hangoei in the coastal northern Baltic Sea. Mar Biol 134:771-777

Lewis J (1991) Cyst-theca relationships in Scrippsiella (Dinophyceae) and related orthoperidinioid genera. Bot Mar 34: 91-106

McQuoid MR, Hobson LA (1995) Importance of resting stages in diatom seasonal succession. J Phycol 31:44-50

Montresor M, Montesarchio E, Marino D, Zingone A (1994) Calcareous dinoflagellate cysts in marine sediments of the Gulf of Naples (Mediterranean Sea). Rev Palaeobot Palynol 84:45-56

Montresor M, Zingone A, Sarno D (1998) Dinoflagellate cyst production at a coastal Mediterranean site. J Plankton Res 20:2291-2312

Nehring S (1995) Dinoflagellate resting cysts as factors in phytoplankton ecology of the North Sea. Helgol Meeresunters 49:375-392

Nuzzo L, Montresor M (1999) Different encystment patterns 
in two calcareous cyst-producing species of the dinoflagellate genus Scrippsiella. J Plankton Res 21:2009-2018

Pfiester LA, Anderson DM (1987) Dinoflagellate reproduction. In: Taylor FJR (ed) The biology of dinoflagellates. Blackwell Science Ltd, Oxford, p 611-648

Pierce RW, Turner JT (1994) Plankton studies in Buzzards Bay, Massachusetts, USA. III. Dinoflagellates, 1987 to 1988. Mar Ecol Prog Ser 112:225-234

Roenneberg T (1996) The complex circadian system of Gonyaulax polyedra. Physiol Plant 96:733-737

Roenneberg T, Rehman J (1996) Nitrate, a nonphotic signal for the circadian system. FASEB J 10:1443-1447

Sicko-Goad L, Stoermer EF, Kociolek JP (1989) Diatom resting cell rejuvenation and formation: time course, species records and distribution. J Plankton Res 11:375-389

Sokal R, Rohlf FJ (1995) Biometry, the principles and practice of statistics in biological research, 3rd edn. WH Freeman \& Co, New York

Sweeney BM, Folli SI (1984) Nitrate deficiency shortens the

Editorial responsibility: Otto Kinne (Editor),

Oldendorf/Luhe, Germany circadian period in Gonyaulax. Plant Physiol (Rockv) 75: 242-245

Tangen K, Brand LE, Blackwelder PL, Guillard RRL (1982) Thoracosphaera heimii (Lohmann) Kamptner is a dinophyte: observations on its morphology and life cycle. Mar Micropaleontol 7:193-212

Wall D, Dale B (1968) Quaternary calcareous dinoflagellates (Calciodinellideae) and their natural affinities. J Paleontol 42:1395-1408

Wyatt T, Jenkinson IR (1997) Notes on Alexandrium population dynamics. J Plankton Res 19:551-575

Zingone A, Montresor M, Marino D (1990) Summer phytoplankton physiognomy in coastal waters of the Gulf of Naples. PSZN I: Mar Ecol 11:157-172

Zonneveld KAF, Höll C, Karwath B, Janofske D, Kerntopf B, Willems H (1999) Calcareous resting cysts as palaeo-environmental tools. In: Fischer G, Wefer G (eds) Use of proxies in paleoceanography: examples from the South Atlantic. Springer-Verlag, Berlin, p 145-164

Submitted: January 18, 2000; Accepted: June 27, 2000 Proofs received from author(s): January 29, 2001 